Does FOMC News Increase Global FX Trading?

Andreas M. Fischer and Angelo Ranaldo

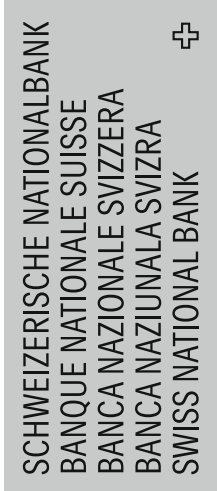

(1)

(4)

응

ro

ô
$\infty$
0
0

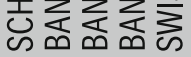

a

(7)

$\frac{1}{2}$

0

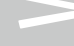

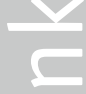

ro

a 
The views expressed in this paper are those of the author(s) and do not necessarily represent those of the Swiss National Bank. Working Papers describe research in progress. Their aim is to elicit comments and to further debate.

ISSN 1660-7716 (printed version)

ISSN 1660-7724 (online version)

๑ 2008 by Swiss National Bank, Börsenstrasse 15, P.0. Box, CH-8022 Zurich 


\title{
Does FOMC News Increase Global FX Trading?*
}

\author{
Andreas M. Fischer ${ }^{1}$ \\ Angelo Ranaldo ${ }^{2}$
}

March 2008

\begin{abstract}
Does global currency volume increase on days when the Federal Open Market Committee (FOMC) meets? To test the hypothesis of excess currency volume on FOMC days, we use a novel data set from the Continuous Linked Settlement (CLS) Bank. The CLS measure captures roughly half of the global trading volume in foreign exchange (FX) markets. We find strong evidence that trading volume increases in the order of $5 \%$ across currency areas on FOMC days during 2003 to 2007. This result holds irrespective of the size of price changes in currency markets and FOMC policy shocks. The new evidence of excess FX trading on FOMC days is inconsistent with standard models of the asset market approach with homogenous agents.
\end{abstract}

Keywords: Trading volume, FOMC, Global linkages

JEL Classification Number: F31, G12

${ }^{1}$ Swiss National Bank and CEPR, Postfach, 8022 Zurich, Switzerland telephone (+41 44) 63132 94, FAX (+41 44) 6318172

e-mail: andreas.fischer@snb.ch

2 Swiss National Bank, Postfach, 8022 Zurich, Switzerland

telephone (+41 44) 63138 26, FAX (+41 44) 6313901

e-mail: angelo.ranaldo@snb.ch

* The authors thank Jürg Mägerle, and Andy Sturm for helpful discussions. Fatum Rasmus, Jim Hughes, the IRTA group, and an anonymous referee offered helpful comments. The views expressed here are those of the authors and do not necessarily reflect the position of the Swiss National Bank. 


\section{Introduction}

Does global currency volume increase on days when the Federal Open Market Committee (FOMC) meets? Currency traders and analysts monitor FOMC meetings for information of imminent changes in the federal funds rate target, because interest rates are a fundamental determinant of exchange rates. Ahn and Melvin (2007), Andersen et al. (2003), Faust et al. (2005), and Hausman and Wongswan (2006) show that foreign exchange (FX) quotes respond in a matter of minutes to public information (news) released by the FOMC. ${ }^{1}$ Models of the asset market approach with homogenous beliefs are the standard framework used by financial economists to explain the price response to FOMC news. However, as Lyons (2001) notes, models of the asset market approach and many microstructure models are silent on issues concerning FX turnover.

While there is consensus in the literature about the currency price reaction to FOMC surprises, little is known about the volume response. A

\footnotetext{
${ }^{1}$ Other recent contributions of FX response to FOMC news include Chaboud et al. (2004), Evans and Lyons (2005), Fatum and Scholnick (2007) Faust et al. (2006) and Simpson et al. (2003). See also recent studies by Bernanke and Kuttner (2005), Ehrmann and Fratzscher (2004), Gürkaynak et al. (2005), and Kuttner (2001) that examine the price response of various financial assets to FOMC announcements.
} 
similar FX volume reaction as currency prices to unanticipated news can be intuitively explained by abnormal portfolio reshuffling in response to FOMC news. This would mean that the well established return-volume relation defined as in Karpoff (1987) for equity markets holds also for FX markets. On the other hand, the existence of abnormal volumes on FOMC dates controlling for policy surprises or price reactions would be difficult to reconcile with models of economic agents with homogenous beliefs and/or identical interpretations.

The objectives of this paper are twofold. First, we test for abnormal trading in global FX markets on FOMC days. Upon establishing the robustness of the FX volume response to public information released after central bank meetings, a second objective is to determine the strength of FOMC policy surprises as a driver of FX volume. We define the FOMC policy surprise as in Kuttner (2005), using information from federal funds futures contracts. The issue of FOMC policy surprise is of importance because Blinder et al. (2007) argue that the objective of central bank communication is either to reduce market noise or to augment market volatility. Hence, focusing on price responses without knowing whether FX volumes rose or fell does not give a complete picture how FX markets respond to central bank communication. 
A difficult hurdle for studies on global FX turnover is measurement. The FX market is borderless, spans different products, and many other market microstructure aspects such as multiple trading platforms and different trading venues (i.e., brokerage or interdealer market). Until now high frequency studies such as Cai et al. (2007) and Chaboud and LeBaron (2001) define FX volume behavior only for specific trading platforms or select markets or as in Melvin and Yin (2003) use price fluctuations as a crude measure of FX volume. Neither of these methods are representative of global FX volume.

Our solution to the measurement problem of capturing global FX trading relies on settlement information from the Continuous Linked Settlement (CLS) Bank in New York. The main advantage of CLS volume data is that decentralized FX trades are centrally settled in New York. The novel data set captures turnover activity in the spot, forward, and futures markets. Since its introduction in September 2002, CLS Bank captures more than half of the FX volume across major currencies at high frequencies.

The evidence in this paper shows an increase in FX turnover for the three largest currencies on 40 FOMC days from 2003 to 2007. Evidence of a volume response to other central bank meetings is weaker. Excess FX trading occurs two full days after the FOMC concludes its meeting. The two-day lag 
is consistent with FX settlement in the spot market. We also find that irrespective of the price change in the exchange rate or FOMC policy shock, CLS currency volume always increases on FOMC days. We also find that Kuttner's (2005) measure of policy surprise does not fully account for the FX volume response on FOMC days. This result means that narrow versions of the asset market approach to exchange rates with homogenous beliefs (i.e., agents interpret public information identically) are overly restrictive.

The paper is organized as follows. Section 1 discusses measurement issues of global FX turnover and presents the CLS data. Section 2 motivates the empirical setup. The same section includes a discussion of the empirical hypotheses, empirical estimation, and hypothesis testing. The empirical evidence for currency volume and FOMC days is presented in section 3. Section 4 offers conclusions.

\section{Data Issues}

This section addresses measurement issues of global FX turnover. First, the gains and limits of a settlement-based definition of FX turnover are discussed. Thereafter, we document the main properties of CLS currency volume. ${ }^{2}$

\footnotetext{
${ }^{2}$ The terms FX volume, FX trading activity, and FX turnover are used interchangeably in this paper. CLS data refer to currency volume and not number of transactions. The
} 


\section{CLS Data and FX Trading Volume ${ }^{3}$}

A serious drawback of empirical studies on FX volume is measurement. Data availability is problematic because the FX market is highly decentralized in terms of location, currency product, and trading platforms. Aggregation is further complicated because FX transactions span different national and legal jurisdictions, time zones, and domestic payments systems.

Previous empirical studies of international finance use three measures of trading volume. Each has its drawbacks. The first is the BIS Triennial Survey of global turnover in traditional product markets (i.e., spot, forward, and swap markets). The three-year frequency and the evolving coverage of the BIS survey on currency volume, however, represent a serious limitation for empirical research studying the dynamics of global FX turnover. A second method used by Goodhart and Figliuoli (1991), Melvin and Peiers Melvin latter is often used as a measure of FX volume. However, since FX trades are standardized our results should hold for the number of transactions.

${ }^{3}$ This section relies heavily on McPortland (2006), Millar and Northcott (2002), and Saywer (2004). They provide further institutional discussions from the perspective of payments systems and infrastructure. See Galati (2002), Kahn and Roberds (2001), and Lacker (2001) for discussions concerning the role of CLS and risks of international payment settlement. 
(2003), and Melvin and Yin (2003) proxies FX volume with price movements, i.e., with indicative quotes or transactions data for specific currency markets. Although favored by empirical researchers because of its high frequency, FX volume remains a latent variable and is market specific. A third approach favored by Chaboud and LeBaron (2001), Chaboud et al. (2004), and Cai et al. (2007) measures transaction volume for select markets and trading platforms. While this latter approach represents a step forward in capturing FX volume at high frequencies, it is still product specific. ${ }^{4}$

Observing market activity at the back-end is a way out of the coveragefrequency dilemma. Rather than measuring currency volume at transaction time, an alternative measure is at settlement time. The main advantage of such a back-end measure of FX volume is that roughly $55 \%$ of the currency transactions in traditional markets are settled in a centralized manner through the CLS Bank in New York. ${ }^{5}$ Moreover, CLS coverage includes FX volume from customer dealers, brokered dealers, and direct dealers. CLS

\footnotetext{
${ }^{4}$ The BIS surveys, for example, mention repeatedly that the growth in the spot market does not move in tandem with the swap market. Table B.1 in BIS (2005) shows that the smaller currency markets, spot and outright forwards, grew faster between 2001 and 2004 (at $60 \%$ ) than the larger swap market $(40 \%)$.

${ }^{5}$ See table 8 of the CPSS (2007) survey.
} 
volume data are available at high frequencies and ensure a representative coverage of global FX turnover.

FX transactions, by definition, involve two currencies, the currency sold and the currency purchased. FX transactions always have a trade date and a settlement date. ${ }^{6}$ The former is the date when both parties come together and define the terms of the trade. The latter, also known as the value date, is the day common to both countries in which the counter-parties of the transaction will pay the agreed currency amount. FX transactions through the CLS Bank can only be settled on business (banking) days common to both countries. European and North American banking holidays often coincide. This however is often not the case for Asia, Africa, and the Middle East. The process of determining value dates for FX transactions is precise. FX trades settle following conventional settlement practices, i.e., spot transactions are settled two days after the trade date; forward transactions are settled 30, 60, or 90 calendar days after the trade date; and futures transactions are settled on the Wednesday following the third Monday of March, June, September, and December. ${ }^{7}$ In the next section, we argue that the settlement convention

\footnotetext{
${ }^{6}$ For some FX products, such as swaps, the two legs of the operations are defined in advance.

${ }^{7}$ These four dates are the International Monetary Market dates: the settlement dates
} 
of $t+2$ for the spot market is linked with volume movements in the spot market.

\section{Data Properties of CLS Volumes}

The empirical sample based on CLS trading volume (unsigned gross flows) considers the top five most actively traded exchange rates: the U.S. dollar (USD), the euro (EUR), the Japanese yen (JPY), the British pound (GBP), and the Swiss franc (CHF). ${ }^{8}$ The daily sample is from 1.10 .2002 to 31.12.2007. The sample's size is restricted by CLS's introduction beginning in late September 2002. CLS currency volumes are denominated in U.S. dollar and are not corrected for double accounting.

CLS currency volumes are characterized by large swings and positive trends. Trading volume for example in the U.S. dollar fluctuated by more than $10 \%$ on days following a bank holiday and grew $1032 \%$ over the sample. In contrast, the volume in the Japanese yen is subject to smaller daily fluctuations and grew less than a third as quick (317\%). A recent CPSS for all FX futures contracts traded on the the International Monetary Market, a division of the Chicago Mercantile Exchange, and on the Financial Instrument Exchange division of the New York Board of Trade.

${ }^{8}$ According to the most recent BIS Triennial Survey (2007), the five currencies account for $80.1 \%(84.5 \%)$ of the total turnover in 2007 (2004). 
(2007) study cited differences in the willingness to adopt CLS technology, the number of FX linked products, and the vehicle status of the USD as major reasons for the non-congruous behavior of CLS currency volumes.

The CLS data were filtered in the following manner. To deal with the inherent trends, we follow Chaboud and LeBaron (2001) and create a detrended volume variable for each currency. The variable, $N V O L_{t}$, is the ratio of today's trading volume to a moving average of the previous 66 daily trading volumes

$$
N V O L_{t}=\frac{v o l_{t}}{\frac{1}{66} \sum_{i=1}^{66} v l_{t-i}}
$$

Next, bank holidays and expiration dates of futures contracts are dropped from the sample to reduce the variance and the effects of potential outliers for the higher moments.

The trend correction in equation (1) does not eliminate daily and weekly effects (i.e., monthly effects were not detected). Following MacDonald and Marsh (1996) in their study on IMM futures volume, we filter the deterministic effects by regressing $\ln \left(N V O L_{t}\right)=n v o l_{t}$ on daily dummies and six lags:

$$
\text { nvol }_{t}==\mathrm{const}+\sum_{k=1}^{4} \alpha_{k} \text { Day }_{k}+\sum_{j=1}^{6} \gamma_{j} \text { nvol }_{t-j},
$$


where $D a y_{k}$ is a dummy that captures day-of-the-week effects. ${ }^{9}$

Table 1 presents statistical information for the residuals from regression equation (2). The insignificant autocorrelation coefficients (AC) reveal that serial correlation is not a problem. Instead, the low $p$-values from the White and the $\mathrm{ARCH}(1)$ tests indicate that the filtered volume series are heteroskedastic. Information from the third and fourth moment shows that the distribution of the residuals is fat-tailed and subject to outliers: a result consistent with FX prices.

\section{Hypothesis Tests and Empirical Setup}

The excess volume hypothesis states that FX traders reshuffle their portfolios on FOMC days. Excess trading may stem from either new information released at the time of the FOMC meeting or from a market response to informed traders. Excess trading for five currencies (USD, EUR, JPY, GBP, and $\mathrm{CHF}$ ) is first tested with the following equation:

$$
\text { nvol }_{t}=\text { const }+\sum_{i=0}^{5} \beta_{i} F O M C_{t-i}+\sum_{k=1}^{4} \alpha_{k} \text { Day }_{k}+\sum_{j=1}^{6} \gamma_{j} n v o l_{t-j}
$$

where $F O M C_{t}$ is a dummy (i.e., $F O M C_{t}=1$ when the FOMC meets, otherwise $\left.F O M C_{t}=0\right)$. The direction criterion of $n v o l_{t}>0$ and $F O M C_{t}>$

\footnotetext{
${ }^{9}$ The lag order was checked with statistical tests.
} 
0 says that $\mathrm{FX}$ volume on FOMC days is larger than the 66-day moving average prior to the meeting.

The dummy variable, $F O M C_{t-i}$, enters $i=\{0, \cdots, 5\}$ to capture FX trading in different FX markets. The first case is for $i=0$. A volume response for $i=0$ implies that FX trading (prior to the FOMC meeting) takes place in the derivatives market or possibly in the spot market. ${ }^{10}$ For the preannouncement effect, we assume that FX traders are either hedging or speculating on (scheduled) future interest rate decisions. The second case is for $i=3$. FX traders respond to news after the FOMC discloses its decision at 2:15 EST and accounts for two-day settlement in the spot market. Since European (Japanese) markets are already closed (not yet open) when the FOMC concludes its deliberations, an international response occurs at $t+1$ and spot market settlement two days later at $t+3$. To capture the duration

\footnotetext{
${ }^{10}$ Numerous studies find that FX markets respond before released information. Peiers (1997) and Dominguez (2003), for example, show that exchange rates respond before central banks intervene in the FX market.
} 
of excess FX volume, we also consider days further out (i.e., $i>3) .{ }^{11}$

To test whether large FOMC shocks generate greater FX trading, we add $F O M C_{t}{ }^{*}\left|\epsilon_{t}^{F F}\right|$ and five lags along with $\left|\epsilon_{t}^{F F}\right|$ and five lags to equation (3):

$$
\begin{aligned}
\text { nvol }_{t}=\text { const } & +\sum_{i=0}^{5} \beta_{i} F O M C_{t-i}+\sum_{f=0}^{5} \kappa_{f}\left|\epsilon_{t-f}^{F F}\right|+\sum_{g=0}^{5} \omega_{g} F O M C_{t-g} *\left|\epsilon_{t-g}^{F F}\right| \\
& +\sum_{h=0}^{5} \delta_{h}\left|\Delta s_{t-h}^{U S D}\right|+\sum_{k=1}^{4} \alpha_{k} \text { Day }_{k}+\sum_{j=1}^{6} \gamma_{j} \text { nvol }_{t-j}
\end{aligned}
$$

The measure of (absolute) policy surprise, $\left|\epsilon_{t}^{F F}\right|$, follows Kuttner (2001). The surprise measure is based on price changes in the federal funds futures contracts (appropriately re-scaled). ${ }^{12}$ Following standard practice, we construct our FOMC shock by working with a 30 minute window between 2:10 EST and 2:40 EST to capture the policy surprise before and after the release of the FOMC statement at 2:15 EST.

Equation (4) also controls for the interaction between absolute FX returns, FX volume, and FOMC events. Jones et al. (1994), Karpoff (1987),

\footnotetext{
${ }^{11}$ Endogeneity is not a problem in this context. The relation between trading volume and FOMC decisions can be interpreted as proof that information from FOMC meetings or anticipated news generate an increase in FX trading activity. This stems from the observation that high FX volume does not cause scheduled FOMC meetings.

${ }^{12}$ Numerous empirical studies find the federal funds futures contract an extremely efficient measure for market expectations of future monetary policy, see Kreuger and Kuttner (1996), Kuttner (2001), Piazzesi and Swanson (2004), Sack (2002), and Sack et al. (2004).
} 
and others have identified a positive correlation between volume and absolute returns for prices of various assets. Higher price volatility is linked with higher turnover activity primarily in the tails of the distribution. To control for absolute returns for the dollar in the volume-FOMC relation, we construct a measure of absolute price returns. This is necessary, because the CLS Bank does not provide an average currency price for settled trades. We build a (daily) trade weighted variable under the assumption that the spot price at noon EST is a valid proxy for settled transactions with CLS Bank. ${ }^{13}$ We denote the (daily) absolute dollar return as $\left|\Delta s_{t}^{U S D}\right|$ and add this variable and five lags to equation (4).

Equation (4) is motivated by the asset market approach to exchange rates with homogenous agents, see Lyons (2001). Bonser-Neal et al. (1998) argue that FOMC news changes expectations, causing the exchange rate to jump to a new level. In our case, a significant coefficient for the cross product, $\left|\epsilon_{t}^{F F}\right|$ (i.e., $\omega_{g}>0$ and $\beta_{i}=0$ ) is consistent with the asset market assumption of homogenous beliefs when testing for excess trading on FOMC days. Alternatively, if $F O M C_{t}$ remains significant even in the presence of $\left|\epsilon_{t}^{F F}\right|$, such

\footnotetext{
${ }^{13}$ The Federal Reserve Bank of New York records the spot rate at noon. The results presented in the next section are not sensitive to other daily spot rate quotes.
} 
evidence says that the policy surprise is not fully capturing the volume response on FOMC days and the asset market model with homogenous beliefs (in the strict sense) is rejected.

\section{Estimation Results}

This section presents evidence of excess FX turnover on 40 scheduled FOMC days for the period 1.1.2003 to 31.12.2007. ${ }^{14}$ First, the relationship between FX volume and FOMC meetings is established. Next, we show that our evidence on FX volume and FOMC meeting is contingent on FOMC news type. Last, evidence on FX returns, FOMC shocks, and FOMC meetings is presented.

\section{Global FX Activity and FOMC Meetings}

This subsection documents evidence of excess FX activity on FOMC days based on the variable of interest, $F O M C_{t-i}$ for $i=\{0,1, \cdots, 5\}$, in equation (3). Table 2 summarizes the regressions for five currency volumes: USD, EUR, JPY, GBP, and CHF. The coefficient estimates for daily effects and lagged $n v o l_{t-j}$ are not shown. Information from Table 2 highlights two ob-

\footnotetext{
${ }^{14}$ The FOMC released a statement on 14.08.2007. We did not include this meeting as a scheduled FOMC meeting. The inclusion or exclusion of this observation has no bearing on our results.
} 
servations about FOMC days. The first is that there is a (near) synchronous response for the five currencies. Currency volume increases on FOMC days at $t$; followed by a decline at $t-1$ and $t-2$; and thereafter with a rise at $t-3$ and $t-4$. The directional pattern is however not significant across currency volumes. The second observation is that only the major three currencies show significant evidence of an excess volume response following an FOMC meeting at the $5 \%$ level. ${ }^{15}$ GBP volume does not respond significantly to FOMC meetings. The FOMC dummy is significant at $t-2$ for CHF volume; a time when global currency volume fell.

A closer look at the strongest volume response to FOMC days reveals that USD volume increases in the order of $5 \%$ at $t, t-3$, and $t-4$. For each of these dates, FX volume is significant. The strong USD volume response stems from the observation that cross currency activity outside of the dollar is limited and that hedging possibilities are scarce in other currencies. The lagged effect for $F O M C_{t-3}$ and $F O M C_{t-4}$ is consistent with international portfolio reshuffling in the cash market after the FOMC concludes its deliberations.

\footnotetext{
${ }^{15}$ All standard errors are corrected using White heteroskedastic-consistent stand errors. A GARCH setup revealed that our empirical results are not sensitive as to how we model the variance.
} 
For the contemporaneous FOMC effect, it is not possible to identify which FX market is responsible for the (pre announcement) impact.

Figure 1 shows the average change in USD volume 15 days before and 20 days after FOMC days. The figure shows the coefficient for $F O M C_{t}$ from 36 regressions specified by equation (2) with $F O M C_{t-i}$ for $i=\{-15,-14, \cdots, 19$, $20\}$. The daily fluctuations in FX turnover are more pronounced before the FOMC meeting than after the meeting. The daily changes in USD volume swing between $-4 \%$ and $+5 \%$. In only one instance at $t+5$ is the coefficient for $F O M C_{t+5}$ significant at the $5 \%$ level. FX volume increases following the FOMC meeting at $t-3$ and $t-4$ and then tappers off. During the 10-day period from $t-5$ to $T-14$, FX volume declines by an accumulated $20 \%{ }^{16}$

To understand whether the result of excess FX volume on FOMC days holds for other central bank meetings, Table 3 presents information on FX volume and scheduled central bank meetings by the European Central Bank (ECB), the Bank of Japan (BoJ), and the Bank of England (BoE). ${ }^{17}$ FX

\footnotetext{
${ }^{16}$ Bomfim (2000) and Jones et al. (1998) claim FOMC days calm stock and bonds. Visually this can be seen in Figure 1, but it is not supported by empirical tests using a GARCH setup.

${ }^{17}$ Excess volume on Swiss National Bank days was not considered, because the number of (non overlapping) observations is less than 10 .
} 
volume is for USD volume and domestic currency volume. Unlike in the case of FOMC days, no congruous response pattern of excess volume emerges for either currency volume for ECB, BoJ, or BoE meetings. The central bank dummy is negatively significant for the ECB at $t$ and for the BoE at $t-1$. The observation that FX activity responds stronger to FOMC meetings than other central bank meetings is consistent with studies by Almeida et al. (1998) that examine the price response of currencies to central bank news. ${ }^{18}$ We interpret the timing evidence based on dummy variable analysis in Tables 2 and 3 as follows: USD volumes increase strongly after the FOMC concludes its meeting but not for other central bank meetings.

\section{USD Volume and FOMC Actions}

The previous subsection treated FOMC days as a deterministic effect irrespective of FOMC actions. In this subsection we present evidence on USD volume and information released after the FOMC meetings. First, we consider whether days when the FOMC changed the federal funds rate target

\footnotetext{
${ }^{18}$ The importance of news from FOMC meetings on FX markets versus news from other central banks has also been examined for money announcements by Ito and Roley (1987) and central bank interventions by Dominguez (2003). More recent comparative studies on central bank communication by Ehrmann and Fratzscher (2007) and De Haan and Jansen (2004) find that FX markets do not respond equally to central bank news.
} 
generated a stronger volume response than on days when the FOMC undertook no change in the target. Table 4 summarizes this information for USD volume. For comparative purposes, the results from $F O M C_{t-i}$ are presented in the first column. In columns (2) and (3) of Table 4, regression estimates for separate FOMC actions are presented: change in $F F$ is a dummy for 18 FOMC days when a change in the federal funds rate target occurred and no change in FF is a dummy for 22 FOMC days when the federal funds rate target remained unchanged. Again, we used equation (3) as our baseline model and show the coefficient estimates for the FOMC dummy only. The regressions for federal funds rate changes or no changes show that the delayed volume response at $t-3$ and $t-4$ (attributed to two-day settlement in the cash market) holds. However, USD volumes respond stronger to FOMC days with a change in the federal funds rate target (column two) than when no change occurred (column three). A null hypothesis of coefficient equality for the two FOMC days is rejected with a $p$-value of 0.001 .

Next, we consider the influence of future interest rate leanings on FX volume. As in Pakko (2005) and Thornton and Wheelock (2000), we review the FOMC statements and classify future FOMC leanings (i.e., future interest rate cuts or increases) into neutral and non-neutral categories. The latter 
group is when the FOMC statement states that if the current assessment of the balance of risks materializes then future changes in the federal funds rate target are warranted, while the former do not indicate a change in the future path of interest rates. ${ }^{19}$ There are 21 neutral leanings versus 19 nonneutral leanings. Columns (5) and (6) in Table 4 show coefficient estimates for non neutral and neutral FOMC leanings from separate regressions. The coefficient estimates show that non neutral leanings with up to the fourth lag generate a larger reaction in USD volume than do neutral leanings. Imminent changes in FOMC policy heighten FX activity. USD volume does not react to our measure of neutral leanings. The null hypothesis that neutral and non-neutral leanings have the same effect on USD volume is rejected with a $p$-value of 0.006 .

\section{USD Volume and Federal Funds Futures}

As a further check of the results in Table 2 and the assumption of homogenous beliefs under the asset price model, we consider whether USD volume responds to policy surprises as defined by equation (4). Table 5 summarizes the expanded regressions for the cross product, $F O M C_{t}{ }^{*}\left|\epsilon_{t}^{F F}\right|$. The main result is that $F O M C_{t-3}{ }^{*}\left|\epsilon_{t-3}^{F F}\right|$ is always significant for alternative specifi-

\footnotetext{
${ }^{19}$ Our classification is available upon request.
} 
cations, upholding the earlier volume-FOMC relation for the spot market. Column (1) presents cross product coefficients from a regression of USD volume on the cross product and five lags with the day of the week dummy and six lags of USD volume. Only the coefficients for $F O M C_{t}{ }^{*}\left|\epsilon_{t}^{F F}\right|$ are shown in Table 5. The variable, $F O M C_{t-3}{ }^{*}\left|\epsilon_{t-3}^{F F}\right|$, has an extremely large coefficient. A $1 \%$ price change (within a half hour time span) in the federal funds futures contract will increase FX trading by more than $200 \%$ for an FOMC day. ${ }^{20}$ The variable, $F O M C_{t-3} *\left|\epsilon_{t-3}^{F F}\right|$, along with the pre-announcement effect for $F O M C_{t}{ }^{*}\left|\epsilon_{t}^{F F}\right|$ are significant at the $5 \%$ level.

Column (2) of Table 5 shows that the coefficient estimates for $F O M C_{t}{ }^{*}\left|\epsilon_{t}^{F F}\right|$ are sensitive to the addition of $F O M C_{t}$ and five lags. Although the significance of $F O M C_{t}{ }^{*}\left|\epsilon_{t}^{F F}\right|$ and $F O M C_{t-3}{ }^{*}\left|\epsilon_{t-3}^{F F}\right|$ is upheld, the F-test of the FOMC dummies in column (2) shows that these variables are significant. The significance of the FOMC dummies means that the strict version of the asset market approach to exchange rates with homogenous beliefs is not fully capturing information related to FOMC days.

Columns (3) and (4) show that the significance of $F O M C_{t-3}{ }^{*}\left|\epsilon_{t-3}^{F F}\right|$ holds when controlling for $\left|\epsilon_{t}^{F F}\right|$ and five lags in the specifications defined in columns

${ }^{20}$ This result $(238 / 48)$ is consistent with the FOMC $C_{t}$ results of $5 \%$ in Table 2. 
(1) and (2). However, this is not true for the pre-announcement effect of $F O M C_{t}{ }^{*}\left|\epsilon_{t}^{F F}\right|$. It is no longer significant at conventional levels. The $p$-value for an F-test for the the FOMC dummies shown in column (4) is 0.07. Again, this says that the FOMC dummies are capturing information around FOMC days that is not correlated with policy surprises, $\left|\epsilon_{t}^{F F}\right|$. An F-test for the (joint) null hypothesis that the coefficients for $\left|\epsilon_{t-f}^{F F}\right|$ for $f=\{0, \cdots, 5\}$ are zero cannot be rejected. ${ }^{21}$

The evidence of the return-volume relation on FOMC days is presented in columns (5) and (6) of Table 5. The main result is that the volume response to FOMC days holds even when we control for absolute returns. The variable, $F O M C_{t-3}{ }^{*}\left|\epsilon_{t-3}^{F F}\right|$, remains significant at the $5 \%$ level regardless whether we control for $F O M C_{t}$ (see column 6). Unlike $\left|\epsilon_{t}^{F F}\right|,\left|\Delta s_{t}^{U S D}\right|$ are found to be positively correlated with daily USD volume. The $p$-values of the F-test show that absolute price returns are significant at conventional levels, extending Karpoff's (1987) finding of return-volume relation for currency markets. ${ }^{22}$

\footnotetext{
${ }^{21}$ We experimented with different windows for $\left|\epsilon_{t}^{F F}\right|$. Regardless if the window is 30 minutes or open to close the results did not change. This result confirms the results in Gürkaynak et al. (2005) for monetary policy shocks and asset prices.

${ }^{22}$ It is important to recall that, unlike $F O M C_{t-3}{ }^{*}\left|\epsilon_{t-3}^{F F}\right|,\left|\Delta s_{t}^{U S D}\right|$ should not be treated as a causal variable of FX volume.
} 
From the significant F-test for $F O M C_{t-g}$, it is possible to determine that large FX volume activity at the time of the FOMC meeting is associated with large exchange rate movements in prices.

We interpret the evidence in Tables 2 to 5 as follows. FOMC meetings are events that generate an increase in FX volume for the three largest currencies. Excess FX trading, particularly for the USD, is observed with a lag following the FOMC meeting and has a duration of two business days; a phenomenon which is longer than FX price responses to FOMC news, see Ahn and Melvin (2007), Andersen et al. (2003), Bonser et al. (1998), Faust et al. (2005), and Hausman and Wongswan (2006). The lagged response in FX turnover is consistent with two-day settlement in the FX spot market. The FOMC response suggests that currency traders reshuffle their portfolios when the FOMC meets and especially in the face of FOMC actions.

It is important to qualify our results in light of potential weaknesses. First, Anderson et al. (2003) showed that FX markets respond to a range of newswire releases and financial market surveys. Our study focuses solely on FOMC meetings as a driver of FX volume, thus an open issue is the FX volume response to FOMC days relative to other forms of news. Second, our sample is dominated by low financial market volatility, see Panetta 
et al. (2006). Although we conjecture that excess FX trading on FOMC days should increase in a period of greater market turbulence with numerous unscheduled FOMC meetings (i.e., post July 2007), the paucity of observations do not allow us to test for this. Third, the analysis focused on the FX turnover response to 40 FOMC meetings. Event studies on FOMC days range between 10 (see, Ahn and Melvin, 2007) and 199 observations (see, Rudebusch, 1995). Despite working with the largest possible sample, it cannot be excluded that the study's empirical results are subject to a small sample bias.

\section{Conclusions}

The paper investigates the dynamics of global FX trading on FOMC days. Until now the FX response to monetary policy actions has focused on price changes with limited insight into how global currency volume behaves. As noted by Lyons (2001) and Blinder et al. (2007), understanding the behavior of global currency volume is important for central bank communication.

We use CLS data on FX settlement volume as our measure of global FX turnover that encompasses transactions from spot, forward, and futures markets. We find that there is a significant increase in global turnover two 
(full) days following a scheduled FOMC meeting. The two-day result is consistent with settlement trading in the spot market and reconfirms the view that the spot market is the most active FX market. We also find that irrespective of the size of the exchange rate change or FOMC news type, global currency volume always increases on FOMC days. The excess trading result says that larger than average portfolio shifts occur after the FOMC deliberates.

Our empirical results have implications for the interaction between exchange rate volume and monetary policy actions. First, the observation that excess FX turnover is identified in the spot market after the FOMC meets means that previous attempts to capture FX turnover in select FX markets such as the futures market cannot be representative of global FX trading. Second, the result that FOMC days generate high levels of FX trading even when accounting for monetary surprises and absolute price changes is not consistent with exchange rate models that assume homogenous agents. Third, the evidence on CLS volume shows that it is difficult to make statements about central bank transparency without knowing what happens to FX volume. Even if central banks communicate transparently (see Blinder et al. (2007)) and a small price response is observed, this should not be 
necessarily interpreted that international portfolio reshuffling will be low. 


\section{References}

Ahn, Seung Chan and Michael Melvin (2007) "Exchange Rates and FOMC Days," Journal of Money Credit and Banking 39(5), pp. 1245-1266.

Almeida, Alvaro, Charles Goodhart, and Richard Payne (1998) "The Effects of Macroeconoic News on High Frequency Exchange Rate Behavior," Journal of Financial and Quantitative Analysis, pp. 383-408.

Andersen, Torben G., Tim Bollerslev, Francis X. Diebold, and Clara Vega (2003) "Micro Effects of Macro Announcements: Real Time Price Discovery in Foreign Exchange," American Economic Review 93), pp. 38-62.

Bank for International Settlements (2007) "Triennial Central Bank Survey: Foreign Exchange and Derivatives Market Activity in 2007," Basel (preliminary draft).

Bank for International Settlements (2005) "Triennial Central Bank Survey: Foreign Exchange and Derivatives Market Activity in 2004," Basel (March).

Bernanke, Ben S. and Kenneth Kuttner (2005) "What Explains the Stock Market's Reaction to Federal Reserve Policy?," Journal of Finance 55, pp. 1221-1257.

Blinder, Alan S., Michael Ehrmann, Marcel Fratzscher, Jakob de Haan, and David-Jan Jansen (2007) "Central Bank Communication and Monetary Policy: A Survey of Theory and Evidence," mimeo.

Bomfim, Antulio (2000) "Pre-Announcement Effects, News, and Volatility: Monetary Policy and Stock Market," mimeo.

Bonser-Neal, Catherine, V. Vance Roley, and Gordon H. Sellon, Jr., (1998) "Monetary Policy Actions, Intervention, and Exchange Rates: A Reexamination of the Empirical Relationships Using Federal Funds Rate Target Data," Journal of Business 71, pp. 147-177.

Cai, Fang, Edward Howorka, and Jon Wongswan (2007) "International Linkages Across trading Regions: Evidence from Foreign Exchange Markets," Journal of International Money and Finance, forthcoming.

Chaboud, Alain, Sergey V. Chernenko, Edward Howorka, Raj S. Krishnasami 
Iyer, Daivd Liu, and Jonathan H. Wright (2004) "The High-Frequency Effects of U.S. Macroeconomic Data Releases on Prices and Trading Activity in the Global Interdealer Foreign Exchange Market," Board of Governors of the Federal Reserve System, International Finance Discussion Papers, No. 823.

Chaboud, Alain and Blake LeBaron (2001) "Foreign Exchange Market Trading Volume and Federal Reserve Intervention," Journal of Futures Markets 21(9), pp. 851-60.

CPSS (2007) "Progress in Reducing Foreign Exchange Settlement Risk," Committee on Payment and Settlement Systems, BIS Basel.

Dominguez, Kathryn M. E. (2003) "The Market Microstructure of Central Bank Intervention," Journal of International Economics 59(1), 25-45.

Ehrmann, Michael and Marcel Fratzscher (2005) "Equal Size, Equal Role? Interest Rate Interdependence between the Euro and United States," Economic Journal 115, pp. 930-950.

Ehrmann, Michael and Marcel Fratzscher (2004) "Taking Stock: Monetary Policy Transmission to Equity Markets," Journal of Money, Credit, and Banking 36, pp. 719-737.

Evans, Martin D.D. and Richard K. Lyons (2005) "Do Currency Markets Absorb News Quickly?' Journal of International Money and Finance 24, pp. 197-217.

Fatum, Rasmus and Barry Scholnick (2007) "Monetary Policy News an Exchange Rate Responses: Do Only Surprises Matter?," Journal of Banking and Finance forthcoming.

Faust, Jon, John Rogers, Jonathan Wright, and Shing-Yi Wang (2006) "The High-Frequency Response of Exchange Rates and Interest Rates to Macroeconomic Announcements," Journal of Monetary Economics 54(1), pp. 1051-11068.

Faust, Jon, John Rogers, Eric Swanson, and Jonathan H. Wright (2003) "Identifying the Effects of Monetary Policy Shocks on Exchange Rates Using High Frequency Data," Journal of the European Economic Association 1, pp. 1051-1068. 
Galati, Gabriele (2002) "Settlement Risk in Foreign Exchange Markets and CLS Bank," BIS Quarterly Review (December), pp. 55-65.

Goodhart, Charles and Luigi Figliuoli (1991) "Every Minute Counts in Financial Markets," Journal of International Money and Finance 10, pp. 23-52.

Gürkaynak, Refet, Brian Sack, Eric Swanson (2005) "Do Actions Speak Louder than Words? The Response of Asset Prices to Monetary Policy Actions and Statements," International Journal of Central Banking 1), pp. 55-93.

Hausman, Joshua and Jon Wongswan (2006) "Global Asset Prices and FOMC Announcements," International Finance Discussion Papers, Board of Governors of the Federral Reserve System, No. 886.

Ito, Takatoshi and V. Vance Roley (1987) "News from the U.S. and Japn Which Moves the yen/dollar Exchange Rate?," Journal of Monetary Economics 19(2), pp. 255-277.

Jansen, David-Jan and Jokob deHaan (2007) "Were Verbal Efforts to Support the Euro Effective? A High Frequency Analysis of ECB Statements," European Journal of Political Economy 23(1), pp. 245-259.

Jones, Charles M., Own Lamont, and Robin L. Lumsdaine (1998) "Macroeconomics News and Bond Market Volatility," Journal of Financial Economics 47, pp. 315-337.

Jones, C. M., G. Kaul, M. L. Lipson (1994) "Transactions, Volume and Volatility," Review of Financial Studies 7, 631-651.

Kahn, Charles M. and William Roberds (2001) "The CLS Bank: A Solution to the Risks of International Payment Settlement?" Carnegie-Rochester Conference Series on Public Policy 54, pp. 191-226.

Karpoff, J. M. (1987) "The Relation Between Price Changes and Trading Volume: A Survey," Journal of Financial and Quantitative Analysis 22, 109-126.

Krueger, Joel T., and Kenneth N. Kuttner (1996) "The Federal Funds Futures Rate as a Predictor of Federal Reserve policy," Journal of Futures Markets 16, pp. 865-879. 
Kuttner, Kenneth N. (2001) "Monetary Policy Surprises and Interest rates: Evidence from teh the Fed Funds Futures Market," Journal of Monetary Economics 47, pp. 523-544.

Lacker, Jeffrey M. (2001) "The CLS Bank: A Solution to the Risks of International Payment Settlement? A Comment," Carnegie-Rochester Conference Series on Public Policy 54, pp. 227-233.

Lyons, Richard K. (2001) "The Microstructure Approach to Exchange Rates," MIT Press.

MacDonald, Ronald and Ian W. Marsh (1996) "Currency Forecasters are Heterogeneous: Confirmation and Consequences," Journal of International Money and Finance 15(5), 665-685.

McPortland, John W. (2006) "Foreign Exchange Trading and Settlement: Past and Present," Chicago Fed Letter Number 225, February.

Melvin, Michael and Bettina Peiers Melvin (2003) "The Global Transmission of Volatility in the Foreign Exchange Market," Review of Economics and Statistics 85(3), pp. 670-679.

Melvin, Michael and Xixi Yin (2003) "Public Information Arrival, Exchange Rate Volatility and Quote Frequency," Economic Journal 110(July), pp. 644-661.

Millar, Paul and Carol Ann Northcott (2002) "CLS Bank: Managing Foreign Exchange Settlement Risk," Bank of Canada Review, (Autumn) pp. 1325 .

Pakko, Michael R. (2005) "On the Information Content of Asymmetric FOMC Policy Statements: Evidence from a Taylor-Rule Perspective," Economic Inquiry 43(3), pp. 558-569.

Panetta, Fabio, Paolo Angelini, Guiseppe Grande, Aviram Levy, Roberto Perli, Pinar Yesin, Stefan Gerlach, Srichander Ramaswamy, and Michela Sctigna (2006) "The Recent Behavior of Financial Market Volatility," BIS Papers No. 29, Bank for International Settlements.

Peiers, Betina (1997) "Informed Traders, Intervention, and Price Leadership: A Deeper View of the Microstructure of the Foreign Exchange Market," Journal of Finance 52(4), 1589-1614. 
Piazzesi, Monika, and Eric T. Swanson (2005) "Futures Prices as RiskAdjusted Forecasts of Monetary Policy," NBER Working Paper 10547.

Rudebusch, Glenn D. (1995) "Federal reserve Interest Rate Targeting, Rational Expectations, and the Term Structure," Journal of Monetary Economics 35(2), pp. 245-274.

Sack, Brian (2002) "Extracting the Expected Path of Monetary Policy from Futures Rates," Journal of Futures Markets 34, pp. 733-754.

Sack, Brian, Eric T. Swanson, and Refet S. Gürkaynak (2004) "Market-based Measures of Monetary Policy Expectations," Board of Governors of the Federal Reserve System FEDS WP 2002-40.

Saywer, David (2004) "Continuous Linked Settlement (CLS) and Foreign Exchange Settlement Risk," Bank of England Financial Stability Review, (December) pp. 86-92.

Simpson, Marc W., Sanjay Ramchanderaywer, and Mukesh Chaudry (2005) "The Impact of Macroeconomic Surprises on Spot and Forward Exchange Markets," Journal of International Money and Finance, (24 pp. 693-718.

Thornton, Daniel L. and David C. Wheelock (2000) "A History of the Asymmetric policy Directive," Federal Reserve Bank of St. Louis Review 82(5), pp. 1-16. 
Table 1: Residual Properties of the (Filtered) CLS Series (2003-2007)

\begin{tabular}{|c|c|c|c|c|c|}
\hline & $\mathrm{CHF}$ & EUR & GBP & JPY & USD \\
\hline Mean & 0.0000 & 0.0000 & 0.0000 & 0.0000 & 0.0000 \\
\hline Median & -0.0041 & -0.0086 & -0.0082 & -0.0059 & -0.0019 \\
\hline Maximum & 0.8255 & 0.6812 & 0.7091 & 0.7314 & 0.6824 \\
\hline Minimum & -0.3899 & -0.3804 & -0.4282 & -0.3711 & -0.6525 \\
\hline Std. Dev. & 0.1256 & 0.1220 & 0.1251 & 0.1294 & 0.1194 \\
\hline Skewness & 0.7948 & 0.7676 & 0.9166 & 1.2677 & 0.4614 \\
\hline Kurtosis & 7.1409 & 5.8413 & 7.0585 & 8.6141 & 9.4118 \\
\hline Jarque-Bera & 534.4920 & 318.5398 & 574.3131 & 905.9700 & 1307.8420 \\
\hline Observations & 652 & 733 & 695 & 573 & 745 \\
\hline $\mathrm{AC} 1$ & 0.0400 & 0.0040 & -0.0090 & -0.0090 & -0.0020 \\
\hline $\mathrm{AC} 2$ & 0.0180 & -0.0150 & -0.0020 & -0.0180 & -0.0220 \\
\hline $\mathrm{AC} 3$ & -0.0100 & -0.0130 & 0.0020 & -0.0160 & 0.0010 \\
\hline $\mathrm{AC} 4$ & -0.0300 & -0.0500 & 0.0170 & -0.0290 & -0.0540 \\
\hline AC5 & -0.0010 & 0.0110 & -0.0020 & -0.0180 & -0.0260 \\
\hline $\mathrm{AC} 6$ & -0.0570 & -0.0020 & -0.0070 & -0.0110 & -0.0230 \\
\hline $\mathrm{AC} 7$ & 0.0130 & -0.0180 & -0.0180 & 0.0020 & -0.0080 \\
\hline $\mathrm{AC} 8$ & 0.0030 & 0.0000 & -0.0330 & 0.0080 & 0.0090 \\
\hline $\mathrm{AC} 9$ & -0.0290 & 0.0200 & 0.0210 & 0.0080 & 0.0170 \\
\hline $\mathrm{AC} 10$ & -0.0010 & -0.0130 & 0.0350 & 0.0110 & -0.0250 \\
\hline White test No cross terms & 0.0590 & 0.1791 & 0.0610 & 0.0003 & 0.0098 \\
\hline Cross terms & 0.0061 & 0.9734 & 0.0061 & 0.0003 & 0.0097 \\
\hline $\operatorname{ARCH}(1)$ & 0.0566 & 0.0822 & 0.0089 & 0.0151 & 0.0265 \\
\hline $\mathrm{ARCH}(2)$ & 0.1805 & 0.2188 & 0.0928 & 0.0430 & 0.1285 \\
\hline $\operatorname{ARCH}(5)$ & 0.3626 & 0.1678 & 0.2562 & 0.2556 & 0.4160 \\
\hline
\end{tabular}

Notes: FX volume in USD and filtered with a 66-day moving average trend excluding holidays,

futures expiration dates, and seasonality. $\mathrm{AC}(\mathrm{x})$ denotes autocorrelation coefficient order $\mathrm{x}$.

White test gives the p-values. $\mathrm{ARCH}(\mathrm{x}) \mathrm{p}$-values of an $\mathrm{ARCH}$ test order $\mathrm{x}$. Bold numbers

denotes significant at the 5 
Table 2: FX Volume and FOMC Meetings

nvol $_{t}=\mathrm{const}+\sum_{i=0}^{5} \beta_{i} F O M C_{t-i}+\sum_{k=1}^{4} \alpha_{k}$ Day $_{k}+\sum_{j=1}^{6} \gamma_{j} n \operatorname{col}_{t-j}$

\begin{tabular}{|c|c|c|c|c|c|}
\hline currency nvol $_{t}$ & USD & EUR & JPY & GBP & $\mathrm{CHF}$ \\
\hline \multirow[t]{2}{*}{$F O M C_{t}$} & $0.0535 * *$ & 0.0421 & 0.0263 & 0.0219 & 0.0320 \\
\hline & $(0.0207)$ & $(0.0262)$ & $(0.0242)$ & $(0.0277)$ & $(0.0208)$ \\
\hline \multirow[t]{2}{*}{$F O M C_{t-1}$} & -0.0009 & -0.0003 & 0.0264 & 0.0162 & 0.0035 \\
\hline & $(0.0328)$ & $(0.0394)$ & $(0.0437)$ & $(0.0447)$ & $(0.0272)$ \\
\hline \multirow[t]{2}{*}{$F O M C_{t-2}$} & -0.0243 & -0.0278 & -0.0148 & -0.0320 & $-0.0469^{* *}$ \\
\hline & $(0.0286)$ & $(0.0238)$ & $(0.0238)$ & $(0.0284)$ & $(0.0234)$ \\
\hline \multirow[t]{2}{*}{$F O M C_{t-3}$} & $0.0546^{* *}$ & 0.0187 & $0.0479 * *$ & 0.0022 & 0.0100 \\
\hline & $(0.0203)$ & $(0.0177)$ & $(0.0239)$ & $(0.0218)$ & $(0.0271)$ \\
\hline \multirow[t]{2}{*}{$F O M C_{t-4}$} & $0.0449^{* *}$ & $0.0342^{*}$ & $0.0452 * *$ & -0.0108 & 0.0041 \\
\hline & $(0.0197)$ & $(0.0179)$ & $(0.0213)$ & $(0.0235)$ & $(0.0202)$ \\
\hline \multirow[t]{2}{*}{$F O M C_{t-5}$} & -0.0300 & $-0.0461^{*}$ & -0.0054 & -0.0079 & -0.0205 \\
\hline & $(0.0221)$ & $(0.0277)$ & $(0.0274)$ & $(0.0263)$ & $(0.0252)$ \\
\hline Number of Obs. & 745 & 804 & 643 & 763 & 804 \\
\hline$R^{2}$ & 0.421 & 0.540 & 0.452 & 0.473 & 0.449 \\
\hline
\end{tabular}

Notes: vol $_{t}$ is FX volume for five currencies (USD, EUR, JPY, GBP, CHF), $F O M C_{t}$ is a dummy for FOMC days, and Day $y_{k}$ is a day-of-the-week dummy. Only the coefficients for FOMC $C_{t}$ in the above regression are shown. * and ** denotes significance at the $10 \%$ and the $5 \%$ level. Standard errors are White heteroskedastic consistent standard errors. Sample is from 1.1.2003 to 31.12.2007. 
Table 3: FX Volume and BoJ, ECB, and BoE Meetings

$n v o l_{t}=\mathrm{const}+\sum_{i=0}^{5} \beta_{i} C B_{t-i}+\sum_{k=1}^{4} \alpha_{k}$ Day $_{k}+\sum_{j=1}^{6} \gamma_{j} n v o l_{t-j}$

\begin{tabular}{|c|c|c|c|c|c|c|}
\hline $\begin{array}{c}\text { currency } \text { nvol }_{t} \\
\text { Central Bank Meeting } C B_{t}\end{array}$ & $\begin{array}{l}\text { USD } \\
\text { ECB }\end{array}$ & $\begin{array}{l}\text { USD } \\
\text { BoJ }\end{array}$ & $\begin{array}{l}\text { USD } \\
\text { BoE }\end{array}$ & $\begin{array}{l}\text { EUR } \\
\text { ECB }\end{array}$ & $\begin{array}{l}\text { JPY } \\
\text { BoJ }\end{array}$ & $\begin{array}{l}\text { GBP } \\
\text { BoE }\end{array}$ \\
\hline$C B_{t}$ & $\begin{array}{c}-0.0709 * * \\
(0.0299)\end{array}$ & $\begin{array}{c}0.0198 \\
(0.0230)\end{array}$ & $\begin{array}{l}-0.0213 \\
(0.0214)\end{array}$ & $\begin{array}{l}-0.0624^{*} \\
(0.0329)\end{array}$ & $\begin{array}{l}-0.0248 \\
(0.0308)\end{array}$ & $\begin{array}{c}0.0054 \\
(0.0218)\end{array}$ \\
\hline$C B_{t-1}$ & $\begin{array}{l}0.0161 \\
(0.0267)\end{array}$ & $\begin{array}{c}0.0322 \\
(0.0238)\end{array}$ & $\begin{array}{c}-0.0421^{* *} \\
(0.0179)\end{array}$ & $\begin{array}{l}-0.0120 \\
(0.0305)\end{array}$ & $\begin{array}{l}0.0317 \\
(0.0351)\end{array}$ & $\begin{array}{c}-0.0543^{* *} \\
(0.0189)\end{array}$ \\
\hline$C B_{t-2}$ & $\begin{array}{l}-0.0169 \\
(0.0316)\end{array}$ & $\begin{array}{c}0.0253 \\
(0.0251)\end{array}$ & $\begin{array}{c}0.0241 \\
(0.0238)\end{array}$ & $\begin{array}{c}0.0159 \\
(0.0218)\end{array}$ & $\begin{array}{l}-0.0047 \\
(0.0380)\end{array}$ & $\begin{array}{r}0.0396 \\
(0.0286)\end{array}$ \\
\hline$C B_{t-3}$ & $\begin{array}{l}-0.0073 \\
(0.0163)\end{array}$ & $\begin{array}{l}-0.0344 \\
(0.0282)\end{array}$ & $\begin{array}{l}0.0251 \\
(0.0239)\end{array}$ & $\begin{array}{l}-0.0126 \\
(0.0208)\end{array}$ & $\begin{array}{l}-0.0038 \\
(0.0334)\end{array}$ & $\begin{array}{l}-0.0233 \\
(0.0300)\end{array}$ \\
\hline$C B_{t-4}$ & $\begin{array}{l}-0.0060 \\
(0.0197)\end{array}$ & $\begin{array}{l}-0.0375 \\
(0.0272)\end{array}$ & $\begin{array}{c}0.0250 \\
(0.0213)\end{array}$ & $\begin{array}{c}0.0058 \\
(0.0214)\end{array}$ & $\begin{array}{l}-0.0342 \\
(0.0318)\end{array}$ & $\begin{array}{c}0.0078 \\
(0.0346)\end{array}$ \\
\hline$C B_{t-5}$ & $\begin{array}{l}-0.0192 \\
(0.0191)\end{array}$ & $\begin{array}{l}-0.0424 \\
(0.0324)\end{array}$ & $\begin{array}{l}-0.0028 \\
(0.0274)\end{array}$ & $\begin{array}{l}-0.0403 \\
(0.0259)\end{array}$ & $\begin{array}{l}-0.0141 \\
(0.0319)\end{array}$ & $\begin{array}{c}0.0156 \\
(0.0214)\end{array}$ \\
\hline Number of Obs. & 745 & 810 & 810 & 768 & 643 & 760 \\
\hline Number of $\mathrm{CB}$ meetings & 55 & 38 & 52 & 55 & 38 & 52 \\
\hline$R^{2}$ & 0.452 & 0.447 & 0.452 & 0.549 & 0.452 & 0.474 \\
\hline
\end{tabular}

Notes: $n v o l_{t}$ is FX volume for four currencies (USD, EUR, JPY, GBP), $C B_{t}$ is a dummy for three central bank meetings (ECB, BoJ, BoE) and $D a y_{k}$ is a day-of-the-week dummy. Only the coefficients for $C B_{t}$ in the above regression are shown. ${ }^{*}$ and ${ }^{* *}$ denotes significance at the $10 \%$ and the $5 \%$ level. Standard errors are White heteroskedastic consistent standard errors. Sample is from 1.1.2003 to 31.12.2007. 
Table 4: USD Volume and FOMC Type

nvol $_{t}=\mathrm{const}+\sum_{i=0}^{5} \beta_{i} F O M C_{t-i}^{*}+\sum_{k=1}^{4} \alpha_{k}$ Day $_{k}+\sum_{j=1}^{6} \gamma_{j} n$ ol $_{t-j}$

\begin{tabular}{|c|c|c|c|c|c|}
\hline$F O M C_{t}^{*}$ & $\begin{array}{c}(1) \\
\text { All }\left(F O M C_{t-i}\right)\end{array}$ & $\begin{array}{c}(2) \\
\text { Change in FF }\end{array}$ & $\begin{array}{c}(3) \\
\text { No Change in FF }\end{array}$ & $\begin{array}{c}(4) \\
\text { non neutral leanings }\end{array}$ & $\begin{array}{c}(5) \\
\text { neutral leanings }\end{array}$ \\
\hline \multirow[t]{2}{*}{$F O M C_{t}^{*}$} & $0.0535^{* *}$ & $0.0809^{* *}$ & 0.0227 & $0.0806^{* *}$ & 0.0202 \\
\hline & $(0.0207)$ & $(0.0262)$ & $(0.0287)$ & $(0.0257)$ & $(0.0346)$ \\
\hline \multirow[t]{2}{*}{$F O M C_{t-1}^{*}$} & -0.0009 & 0.03989 & -0.0068 & 0.0404 & 0.0092 \\
\hline & $(0.0328)$ & $(0.0588)$ & $(0.0258)$ & $(0.0510)$ & $(0.0358))$ \\
\hline \multirow[t]{2}{*}{$F O M C_{t-2}^{*}$} & -0.0243 & -0.0586 & 0.0353 & -0.0291 & -0.0430 \\
\hline & $(0.0286)$ & $(0.0429)$ & $(0.0272)$ & $(0.0491)$ & $(0.0360)$ \\
\hline \multirow[t]{2}{*}{$F O M C_{t-3}^{*}$} & $0.0546^{* *}$ & $0.0721^{* *}$ & $0.0476^{* *}$ & $0.0737^{* *}$ & -0.0243 \\
\hline & $(0.0203)$ & $(0.0177)$ & $(0.0209)$ & $(0.0345)$ & $(0.0362)$ \\
\hline \multirow[t]{2}{*}{$F O M C_{t-4}^{*}$} & $0.0449^{* *}$ & $0.0647^{* *}$ & $0.0675^{* *}$ & $0.1001^{* *}$ & 0.0217 \\
\hline & $(0.0197)$ & $(0.0179)$ & $(0.0265)$ & $(0.0296)$ & $(0.0411)$ \\
\hline \multirow[t]{2}{*}{$F O M C_{t-5}^{*}$} & -0.0300 & 0.0148 & 0.0004 & 0.0301 & $0.0815^{* *}$ \\
\hline & $(0.0221)$ & $(0.0255)$ & $(0.0306)$ & $(0.0283)$ & $(0.0416)$ \\
\hline Number of Obs. & 745 & 745 & 745 & 745 & 745 \\
\hline Number of FOMC meetings & 40 & 18 & 22 & 19 & 21 \\
\hline$R^{2}$ & 0.421 & 0.417 & 0.406 & 0.417 & 0.413 \\
\hline
\end{tabular}

Notes: $n v o l_{t}$ is USD volume only, FOMC $C_{t}^{*}$ is a dummy for FOMC days and the following conditions (FOMC day,

change in the federal funds rate target $(\mathrm{FF})$, no change in the federal funds rate target, non neutral leaning,

neutral leaning) and $D a y_{k}$ is a day-of-the-week dummy. Only the coefficients for $F O M C_{t}^{*}$ in the above regression

are shown. ${ }^{*}$ and $* *$ denotes significance at the $10 \%$ and the $5 \%$ level. Standard errors are White heteroskedastic consistent standard errors. Sample is from 1.1.2003 to 31.12 .2007 . 
Table 5: USD Volume and FOMC Shocks

$$
\begin{aligned}
\text { nvol }_{t}= & \text { const }+\sum_{i=0}^{5} \omega_{i} F O M C_{t-i}{ }^{*}\left|\epsilon_{t-i}^{F F}\right|+\sum_{f=0}^{5} \kappa_{f}\left|\epsilon_{t-f}^{F F}\right|+\sum_{g=0}^{5} \beta_{g} F O M C_{t-g}+\sum_{h=0}^{5} \delta_{h}\left|\Delta s_{t-h}^{U S D}\right| \\
& +\sum_{k=1}^{4} \alpha_{k} D_{a y_{k}}+\sum_{j=1}^{6} \gamma_{j} \text { nvol }_{t-j}
\end{aligned}
$$

\begin{tabular}{|c|c|c|c|c|c|c|}
\hline restrictions in (4) & $\delta_{h}=\beta_{g}=\kappa_{f}=0$ & $\begin{array}{c}(2) \\
\delta_{h}=\kappa_{f}=0\end{array}$ & $\begin{array}{c}(3) \\
\delta_{h}=\beta_{g}=0\end{array}$ & $\begin{array}{c}(4) \\
\delta_{h}=0 \\
\end{array}$ & $\begin{array}{c}(5) \\
\beta_{g}=0\end{array}$ & $\begin{array}{c}(6) \\
\text { none }\end{array}$ \\
\hline$F O M C_{t}{ }^{*}\left|\epsilon_{t}^{F F}\right|$ & $\begin{array}{l}0.4554^{* *} \\
(0.1577)\end{array}$ & $\begin{array}{l}0.3070^{* *} \\
(0.1089)\end{array}$ & $\begin{array}{l}0.8330 \\
(0.6154)\end{array}$ & $\begin{array}{c}0.6454 \\
(0.5975)\end{array}$ & $\begin{array}{l}1.0642 * \\
(0.6005)\end{array}$ & $\begin{array}{c}0.8403 \\
(0.5827)\end{array}$ \\
\hline$F O M C_{t-1} *\left|\epsilon_{t-1}^{F F}\right|$ & $\begin{array}{c}0.6765 \\
(1.3754)\end{array}$ & $\begin{array}{l}0.8708 \\
(1.3572)\end{array}$ & $\begin{array}{c}1.1243 \\
(1.5095)\end{array}$ & $\begin{array}{c}1.4632 \\
(1.4856)\end{array}$ & $\begin{array}{c}1.3032 \\
(1.5391)\end{array}$ & $\begin{array}{c}1.5819 \\
(1.5171)\end{array}$ \\
\hline$F O M C_{t-2}{ }^{*}\left|\epsilon_{t-2}^{F F}\right|$ & $\begin{array}{c}1.1447 \\
(1.1835)\end{array}$ & $\begin{array}{l}1.7143 \\
(1.3882)\end{array}$ & $\begin{array}{c}1.8773 \\
(1.3337)\end{array}$ & $\begin{array}{c}2.0417 \\
(1.3328)\end{array}$ & $\begin{array}{c}1.7391 \\
(1.2564)\end{array}$ & $\begin{array}{c}1.8860 \\
(1.2594)\end{array}$ \\
\hline$F O M C_{t-3} *\left|\epsilon_{t-3}^{F F}\right|$ & $\begin{array}{l}2.3689^{* *} \\
(0.5606)\end{array}$ & $\begin{array}{l}2.0502^{* *} \\
(0.5974)\end{array}$ & $\begin{array}{l}1.9988^{* *} \\
(0.83332)\end{array}$ & $\begin{array}{l}1.9303^{* *} \\
(0.8541)\end{array}$ & $\begin{array}{l}2.0571^{* *} \\
(0.8321)\end{array}$ & $\begin{array}{l}1.9303^{* *} \\
(0.8527)\end{array}$ \\
\hline$F O M C_{t-4} *\left|\epsilon_{t-4}^{F F}\right|$ & $\begin{array}{c}1.2539 \\
(0.7832)\end{array}$ & $\begin{array}{c}0.6123 \\
(0.7081)\end{array}$ & $\begin{array}{c}1.3207 \\
(0.9928)\end{array}$ & $\begin{array}{c}1.3750 \\
(0.9610)\end{array}$ & $\begin{array}{l}1.0528 \\
(0.9074)\end{array}$ & $\begin{array}{c}1.0989 \\
(0.8918)\end{array}$ \\
\hline$F O M C_{t-5} *\left|\epsilon_{t-5}^{F F}\right|$ & $\begin{array}{l}-0.0571 \\
(0.4309)\end{array}$ & $\begin{array}{l}-0.0037 \\
(0.4916)\end{array}$ & $\begin{array}{c}0.0252 \\
(0.6374)\end{array}$ & $\begin{array}{c}0.0935 \\
(0.6181)\end{array}$ & $\begin{array}{c}0.2653 \\
(0.6348)\end{array}$ & $\begin{array}{c}0.3050 \\
(0.6138)\end{array}$ \\
\hline Sig. Test ( $p$-value) & & & & & & \\
\hline $\begin{array}{c}\Sigma_{f=0}^{J} \kappa_{f}\left|\epsilon_{t-f}^{\kappa}\right| \\
\Sigma_{h=0}^{5} \delta_{h}\left|\Delta s_{t-h}^{U S D}\right| \\
\Sigma_{g=0}^{5} \omega_{g} F O M C_{t-g}\end{array}$ & & 0.050 & 0.813 & 0.070 & 0.090 & $\begin{array}{l}0.016 \\
0.012\end{array}$ \\
\hline Number of Obs. & 745 & 745 & 745 & 745 & 745 & 745 \\
\hline$R^{2}$ & 0.412 & 0.422 & 0.414 & 0.428 & 0.423 & 0.436 \\
\hline
\end{tabular}

Notes: nvolt is USD volume, FOMCt is a dummy for FOMC days, $\left|\epsilon_{t}^{F F}\right|$ is the absolute value of federal funds rate shock defined by Kuttner (2001), $\left|\Delta s_{t}^{U S D}\right|$ is the absolute daily price change in (trade weighted) US dollar, and Dayk is a day of the week dummy. Only the coefficients for $F O M C_{t}{ }^{*}\left|\epsilon_{t}^{F F}\right|$ in the above regression are shown. Sig. Test is an F-test for the significance of the listed variables and their lags (p-values are shown). ${ }^{*}$ and ${ }^{* *}$ denotes significance at the $10 \%$ and the $5 \%$ level. Standard errors are White heteroskedastic consistent standard errors. Sample is from 1.1.2003 to 31.12 .2007 . 
Figure 1: Average change in USD volume before and after a FOMC day

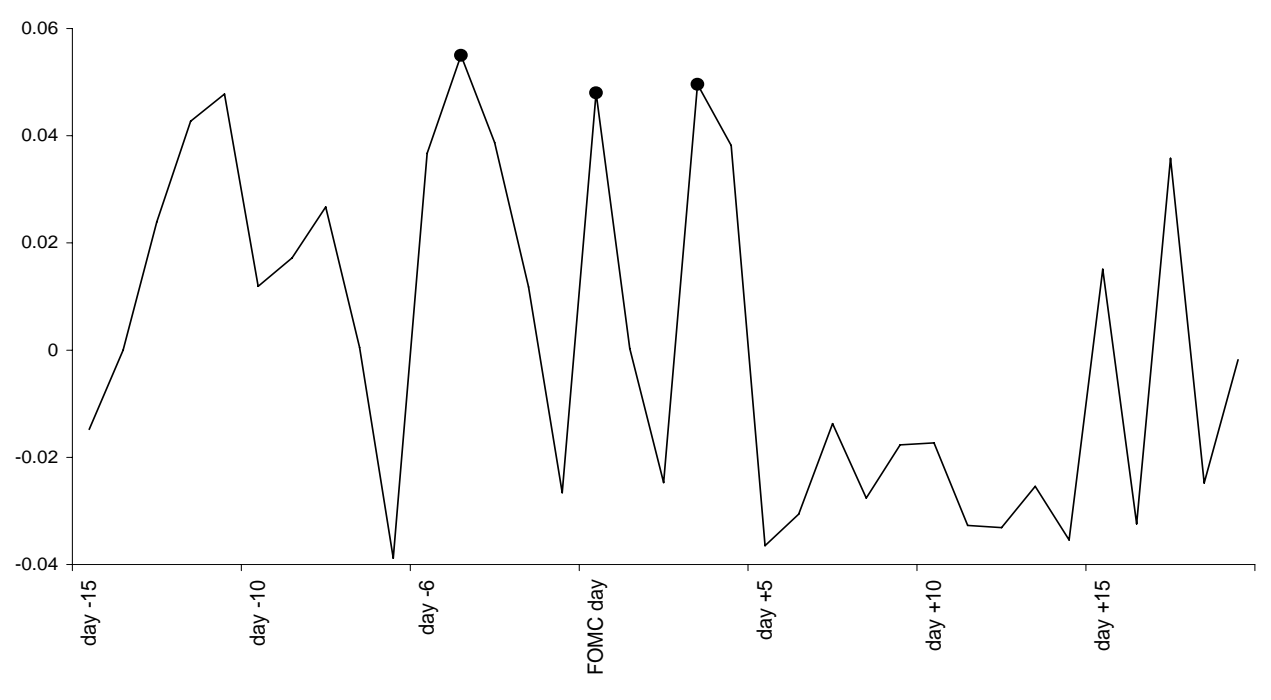

Note: Shaded point denotes significance at the $5 \%$ level. 


\section{Swiss National Bank Working Papers published since 2004:}

2004-1 Samuel Reynard: Financial Market Participation and the Apparent Instability of Money Demand

2004-2 Urs W. Birchler and Diana Hancock: What Does the Yield on Subordinated Bank Debt Measure?

2005-1 Hasan Bakhshi, Hashmat Khan and Barbara Rudolf: The Phillips curve under state-dependent pricing

2005-2 Andreas M. Fischer: On the Inadequacy of Newswire Reports for Empirical Research on Foreign Exchange Interventions

2006-1 Andreas M. Fischer: Measuring Income Elasticity for Swiss Money Demand: What do the Cantons say about Financial Innovation?

2006-2 Charlotte Christiansen and Angelo Ranaldo: Realized Bond-Stock Correlation: Macroeconomic Announcement Effects

2006-3 Martin Brown and Christian Zehnder: Credit Reporting, Relationship Banking, and Loan Repayment

2006-4 Hansjörg Lehmann and Michael Manz: The Exposure of Swiss Banks to Macroeconomic Shocks - an Empirical Investigation

2006-5 Katrin Assenmacher-Wesche and Stefan Gerlach: Money Growth, Output Gaps and Inflation at Low and High Frequency: Spectral Estimates for Switzerland

2006-6 Marlene Amstad and Andreas M. Fischer: Time-Varying Pass-Through from Import Prices to Consumer Prices: Evidence from an Event Study with Real-Time Data

2006-7 Samuel Reynard: Money and the Great Disinflation

2006-8 Urs W. Birchler and Matteo Facchinetti: Can bank supervisors rely on market data? A critical assessment from a Swiss perspective

2006-9 Petra Gerlach-Kristen: A Two-Pillar Phillips Curve for Switzerland

2006-10 Kevin J. Fox and Mathias Zurlinden: On Understanding Sources of Growth and Output Gaps for Switzerland

2006-11 Angelo Ranaldo: Intraday Market Dynamics Around Public Information Arrivals

2007-1 Andreas M. Fischer, Gulzina Isakova and Ulan Termechikov: Do FX traders in Bishkek have similar perceptions to their London colleagues? Survey evidence of market practitioners' views 
2007-2 Ibrahim Chowdhury and Andreas Schabert: Federal Reserve Policy viewed through a Money Supply Lens

2007-3 Angelo Ranaldo: Segmentation and Time-of-Day Patterns in Foreign Exchange Markets

2007-4 Jürg M. Blum: Why `Basel II’ May Need a Leverage Ratio Restriction

2007-5 Samuel Reynard: Maintaining Low Inflation: Money, Interest Rates, and Policy Stance

2007-6 Rina Rosenblatt-Wisch: Loss Aversion in Aggregate Macroeconomic Time Series

2007-7 Martin Brown, Maria Rueda Maurer, Tamara Pak and Nurlanbek Tynaev: Banking Sector Reform and Interest Rates in Transition Economies: Bank-Level Evidence from Kyrgyzstan

2007-8 Hans-Jürg Büttler: An Orthogonal Polynomial Approach to Estimate the Term Structure of Interest Rates

2007-9 Raphael Auer: The Colonial Origins Of Comparative Development: Comment. A Solution to the Settler Mortality Debate

2007-10 Franziska Bignasca and Enzo Rossi: Applying the Hirose-Kamada filter to Swiss data: Output gap and exchange rate pass-through estimates

2007-11 Angelo Ranaldo and Enzo Rossi: The reaction of asset markets to Swiss National Bank communication

2007-12 Lukas Burkhard and Andreas M. Fischer: Communicating Policy Options at the Zero Bound

2007-13 Katrin Assenmacher-Wesche, Stefan Gerlach, and Toshitaka Sekine: Monetary Factors and Inflation in Japan

2007-14 Jean-Marc Natal and Nicolas Stoffels: Globalization, markups and the natural rate of interest

2007-15 Martin Brown, Tullio Jappelli and Marco Pagano: Information Sharing and Credit: Firm-Level Evidence from Transition Countries

2007-16 Andreas M. Fischer, Matthias Lutz and Manuel Wälti: Who Prices Locally? Survey Evidence of Swiss Exporters

2007-17 Angelo Ranaldo and Paul Söderlind: Safe Haven Currencies 
2008-1 Martin Brown and Christian Zehnder: The Emergence of Information Sharing in Credit Markets

2008-2 Yvan Lengwiler and Carlos Lenz: Intelligible Factors for the Yield Curve

2008-3 Katrin Assenmacher-Wesche and M. Hashem Pesaran: Forecasting the Swiss Economy Using VECX* Models: An Exercise in Forecast Combination Across Models and Observation Windows

2008-4 Maria Clara Rueda Maurer: Foreign bank entry, institutional development and credit access: firm-level evidence from 22 transition countries

2008-5 Marlene Amstad and Andreas M. Fischer: Are Weekly Inflation Forecasts Informative?

2008-6 Raphael Auer and Thomas Chaney: Cost Pass Through in a Competitive Model of Pricing-to-Market

2008-7 Martin Brown, Armin Falk and Ernst Fehr: Competition and Relational Contracts: The Role of Unemployment as a Disciplinary Device

2008-8 Raphael Auer: The Colonial and Geographic Origins of Comparative Development

2008-9 Andreas M. Fischer and Angelo Ranaldo: Does F0MC News Increase Global FX Trading? 
Swiss National Bank Working Papers are also available at www.snb.ch, section Publications/Research Subscriptions or individual issues can be ordered at Swiss National Bank, Fraumünsterstrasse 8, CH-8022 Zurich, fax+41 4463181 14, E-mail library@snb.ch 